\title{
IMPLEMENTASI PROGRAM DAKWAH SEBAGAI SARANA PENANAMAN NILAI PENDIDIKAN AGAMA ISLAM UNTUK PENINGKATAN AKHLAK DAN PRAKTEK IBADAH SISWA DI SMP 11 MARET KEC. AMBARAWA KAB. PRINGSEWU
}

\author{
Muhtarom, Eri Purwanti, Ulfah Umurohmi \\ Jl. Raya Wonokriyo Gadingrejo Pringsewu \\ Email: stitpringsewu@gmail.com
}

\begin{abstract}
The role of the planting program of Islamic education in public and private schools is still very minimal. Planting of Islamic education as there are only in environment of school that religion based. But in junior high school 11Maret Sumber Agung, whose status as private schools were able to bring the exclusive through the study religious invitation program. This Program able to increase attitude or morality of the students as well as the activities of worship student in school environment.

The purpose of this study was to determine the role of religious invitation program on the attitudes or moral and religious practices of students in the school. This study uses a quantitative descriptive approach. The results of this study showed an increase in students' attitudes and moral and religious practices in school as many as $25 \%$ from $52.5 \%$ to be $77.5 \%$.

Abstrak

Peran program penanaman pendidikan islam di sekolah umum dan swasta masih sangat minim sekali. Penanaman pendidikan agama islam seakan hanya ada dilingkungan sekolah yang berbasis agama. Akan tetapi di SMP 11 Maret Sumber Agung, yang statusnya sebagai sekolah swasta umum mampu memunculkan kekhasanya melalui kajian program dakwah keagamaan. Program initernyata mampu meningkatkan sikap atau akhlaq siswa serta kegiatan peribadatan siswa dilingkungan sekolah.

Tujuan penelitian ini adalah untuk mengetahui peran program dakwah keagamaan terhadap sikap atau akhlak serta praktek ibadah siswa di sekolah. Penelitian ini menggunakan pendekatan deskriptif kuantitatif. Hasil dari penelitian ini menunjukkan adanya peningkatan sikap dan akhlak siswa serta praktek ibadah di sekolah sebesar $25 \%$ dari $52,5 \%$ menjadi $77,5 \%$.
\end{abstract}

Kata kunci: Dakwah, Akhlaq, Praktek ibadah. 


\section{A. PENDAHUluan}

Terjadinya perkembangan global di segala bidang kehidupan pada saat ini, selain mengindikasikan kemajuan umat disatu pihak, juga mengindikasikan kemunduran akhlak di pihak lain. Kemajuan pengembangan IPTEK oleh manusia yang tidak seimbang dengan kemajuan moral akhlak, telah memunculkan gejala baru berupa krisis akhlak terutama terjadi di kalangan remaja yang memiliki kondisi jiwa yang labil dan emosi yang belum seimbang cenderung mudah dipengaruhi.

Sebagaimana yang telah dijelaskan oleh Ilyas (2009:2), akhlak merupakan sifat yang tertanam dalam jiwa, yang akan muncul secara spontan tanpa memerlukan pertimbangan atau pemikiran terlebih dahulu, serta tidak memerlukan dorongan dari luar. Gambaran akhlak yang baik telah tercatat dalam Al Qur'an dan Al Hadist sebagaimana yang telah dilakukan oleh Nabi Muhammad SAW yang harus dijadikan contoh teladan yang ideal. Pendidikan akhlak adalah pendidikan yang paling penting dalam kehidupan umat manusia, karena di antara perhiasan yang paling mulia bagi manusia sesudah Iman, taat dan takut kepada Allah, adalah akhlak yang mulia. "Sopan santun"(akhlak) adalah bagian dari agama. Menurut pengamat Barat memandang "sikap kaum Muslim lebih mengagungkan sopan-santun" (Amin, 1997: 13).

Harapan untuk mencapai pada tertanamnya akhlaq dalam setiap individu khususnya generasi muda Indonesia masih banyak yang belum terkondisikan. Berdasarkan survey tahun 2010 Komisi Nasional Perlindungan Anak (Komnas Anak) merilis data yang menyebutkan 62,7 persen remaja siswi SMP di Indonesia sudah tidak perawan. Hasil lain dari survei itu menyebutkan 93,7 persen siswa SMP dan SMA pernah melakukan ciuman, 21,2 persen remaja SMP mengaku pernah aborsi, dan 97 persen remaja SMP dan SMA pernah melihat film porno. Data tersebut dirilis oleh Komnas Anak menyusul semakin maraknya peredaran film porno maupun adegan porno di tengah masyarakat melalui internet,(http://beritalampung.blogspot.co.id/2010/0 6/berita-lampung-komisi-nasional.html)

Kembali pada khitah pendidikan ( UU RI No.20 th. 2003) menyatakan bahwa pendidikan adalah "usaha sadar dan terencana untuk mewujudkan suasana belajar dan proses pembelajaran agar peserta didik secara aktif mengembangkan potensi dirinya untuk memiliki kekuatan spiritual keagamaan, pengendalian diri, kepribadian, kecerdasan, akhlak mulia, serta ketrampilan yg diperlukan dirinya, masyarakat, bangsa dan negara." Pengertian pendidikan tersebut dapat diejawantahkan dalam Pendidikan Agama Islam yang responsif dan antisipatif terhadap perkembangan zaman, yaitu proses pendidikan yang dilakukan untuk membimbing tingkah laku manusia melalui revitalisasi pendidikan islam di setiap sekolah. Dr. Muhammad Javad as-Sahlani, dalam At-Tarbiyah wa at-Ta'lim fi al-Qur'an alKarim, mendefinisikan pendidikan Islam sebagai "Proses mendekatkan manusia kepada tingkat kesempurnaan, dan mengembangkan kemampuannya..”. Definisi ini menunjukkan bahwa prinsip-prinsip dakwah Islam dalam pendidikan didasarkan pada ayat-ayat Al Quran. Soejoeti (2002:13) memberikan pengertian bahwa pendidikan islam adalah jenis pendidikan yang lebih menekankan pada nilai-nilai kehidupan sebagai Primer Goals (tujuan utama) dari proses pembentukan dan pengejawantahan ajaran-ajaran islam.

Berbagai bentuk kegiatan pendidikan islam inilah yang kemudian disebut dengan istilah dakwah. Dakwah berasal dari kata "Da'aa" yang berarti mengajak, mengundang, menyeru, memanggil, berdiskusi. Dakwah pada hakikatnya adalah ajaran kepada yang baik dan mencegah yang munkar (Syukir,1983: 1). Dakwah difahami umat Islam baik dari aspek pengertian maupun implementasinya, banyak dan mereka menganggap dakwah berperan strategis serta menentukan dalam kerangka pembinaan mental dan sprirual, (Astati, 2013:1).

Berdasarkan fenomena dan konsep dakwah islam yang telah dipaparkan di atas menunjukkan bahwa pentingnya program dakwah untuk disampaikan dalam lembaga pendidikan dasarmenengah-atas sebagai bentuk pembinaan mental dan spritual anak didik. Akan tetapi dalam dekade ini pusat kekuatan pengembangan dakwah islam bagi pelajar sekolah didominasi oleh sekolah yang berbasis agama (madrasah). Stereotrotip atau pandangan bahwa madrasah sebagai garda depan pengembangan pendidikan agama menjadikan program-program kegiatan keagaman baik dari pihak pemerintah maupun lembaga pendidikan di bawah naungan Non-DEPAG (sekolah umum) kurang berinisiatif untuk membentuk kegiatan ekstrakurikuler berbasis keagamaan. Hal inilah yang kemudian menarik minat penulis untuk melakukan kajian tentang kegiatan dakwah sebagai sarana penanaman pendidikan islam di sekolah umum.

Implementasi Pendidikan Agama Islam menjadi sangat penting, tidak hanya disekolah dengan basis agama, akan tetapi sekolah umum perlu mendapat perhatian yang lebih. Sebagai pendidikan antisipatoris, pendidikan agama islam memiliki tanggung jawab membangun karakter siswa yang mulia. Dalam rangka implementasi tersebut, maka SMP 11 Maret Kecamatan Ambarawa Kab. Pringsewu yang merupakan sekolah swasta umum memiliki cita-cita dan harapan dapat membangun akhlak dan ibadah siswa melalui kegiatan ekstra kurikuler yaitu penyelenggaraan program dakwah. 
Kegiatan ekstra kurikuler program dakwah adalah sebagai benteng siswa dari pengaruh negatif globalisasi. Hal ini disebabkan, kurang efektifnya jam pelajaran untuk pendidikan Agama Islam yang disediakan di sekolah umum dianggap sebagai penyebab utama siswa kurang memahami, menghayati dan mengamalkan ajaran Agama Islam. Alasan inilah yang mendorong penulis untuk melakukan penelitian dengan judul "Implementasi Program Dakwah sebagai Sarana Penanaman Nilainilai Pendidikan Agama Islam untuk Peningkatan Akhlak dan Praktek Ibadah Siswa di SMP 11 Maret Kecamatan Ambarawa Kab. Pringsewu."

\section{B. TUJUAN PENELITIAN}

Tujuan penelitian ini adalah untuk mengetahui pelaksanaan program dakwah di SMP 11 Maret Kecamatan Ambarawa Kab. Pringsewu sebagai sarana penanaman nilai-nilai Pendidikan Agama Islam, implikasi dari implementasi program dakwah tersebut terhadap akhlak dan ibadah siswa di SMP 11 Maret Kecamatan Ambarawa Kab. Pringsewu, serta faktor pendukung dan penghambat dalam implementasi program dakwah yang di laksanakan di SMP 11 Maret Kecamatan Ambarawa Kab. Pringsewu.

\section{1) Ibadah}

Menurut fuqoha, ibadah yaitu Segala hukum yang dikerjakan untuk mengharap pahala di akhirat, dikerjakan sebagai tanda pengabdian kita kepada Allah (Shiddiqy:2000:7).Pengamalan ibadah yakni perbuatan yang dilakukan seseorang sebagai usaha menghubungkan dan mendekatkan diri kepada Allah dengan taat melaksanakan segala perintah dan anjuran-Nya serta menjauhi segala larangannya.

Menurut IbnuTaimiyah (661-728 H/1262$1327 \mathrm{M})$ ibadah mencakup semua bentuk cinta dan kerelaan kepada Allah, baik dalam perkataan maupun perbuatan, lahir dan bathin, maka yang termasuk ke dalam hal ini adalah shalat, zakat, puasa, haji, benar dalam pembicaraan, menjalankan amanah, berbuat baik kepada orang tua, menghubungkan silaturrahmi, memenuhi janji, amarma'ruf nahi munkar, jihad terhadap orang kafir dan munafik, berbuat baik kepada tetangga, anak yatim, fakir miskin, dan ibn sabil, berdo'a, berzikir,membaca Al-Qur'an, ikhlas, sabar, syukur, rela menerima ketentuan Allah swt, tawwakal, raja' (berharap atas rahmat), khauf (takut terhadap azab), dan lain sebagainya.

\section{C). METODE PENELITIAN}

Penelitian ini menggunakan pendekatan deskriptif kuantitatif. Subjek penelitian adalah siswa SMP 11 maret kec. Ambarawa Kab Pringsewu. Penelitian ini menggunakan stratified sampling dari populasi yang ada di tempat penelitian. Pengunaaan sampel tersebut diharapkan dari berbagai tingkatan status yang ada di sekolah mampu didapatkan kevalidan data. Untuk mendapatkan kevalidan data akan dilakukan trianggulasi data.

Teknik pengumpulan data yang digunakan dalam penelitian ini adalah kuesioner (angket), observasi, dokumentasi dan wawancara. Sehingga dalam penelitian ini alat pengumpul data yang digunakan adalah lembar angket, pedoman observasi, pedoman wawancara dan pedoman dokumentasi. Data hasil dari wawancara dan angket kemudian akan ditransformasikan ke dalam nilai-nilai sehingga mempermudah peneliti untuk menganalisis dan membuat kesimpulan akhir.

Teknis analisisnya menggunakan analisis crosstab untuk mengetahui seberapa besar implementasi pendidikan islam melalui program dakwah keagamaan terhadap peningkatan sikap, akhlak dan praktek ibadah siswa di SMP 11 maret Kec. Ambarawa Kab. Pringsewu.

\section{D). HASIL DAN PEMBAHASAN}

\section{1) Profil SMP 11 Maret kec. Ambarawa Kab.Pringsewu \\ SMP 11 Maret Kec. Ambarawa Terletak} di Jl. Makam Sumber Agung Timur, Kecamatan Ambarawa, Kabupaten Pringsewu, Propinsi Lampung. Dipimpin oleh seorang Kepala sekolah yaitu Ibu Suryati. SMP 11 Maret Kec. Ambarawa Kab. Pringsewu adalah sekolah swasta dibawah naungan yayasan yang memiliki tujuan yaitu:

a) Membangun dan menumbuh kembangkan nilainilai keimanan, ketakwaan pada seluruh warga sekolah.

b) Membangun Sumber Daya Manusia (SDM) Pendidik dan tenaga kependidikan yang berkualitas.

c) Pembelajaran berorientasi kepada kearifan lokal dan Nasional.

d) Mengembangkan empat pilar Pendidikan:

- Learning to know (belajar mengetahui),

- Learning to do (belajar melakukan sesuatu), c; Learning to be (belajar menjadi sesuatu),

- Learning to live together (belajar hidup bersama).

Dengan demikian Visi dan Misi SMP 11 Maret Kec. Ambarawa Kabupaten Pringsewu berorientasi menjadi sekolah yang kreatif, edukatif, berkepribadian, berakhlakul karimah, berwawasan 
lingkungan dan budaya yang didasari keimanan dan ketakwaan.

Dalam rangka mencapai tujuan pendidikan SMP 11 Maret Kec. Ambarawa Kabupaten Pringsewu menerapkan berbagai kegiatan ekstra kurikuler yang mampu mendidik dan mengasah kemampuan siswa dalam bergaul, bersikap dan berakhlak yang mulia. Salah satu program kegiatan yang dicetuskan oleh sekolah adalah kegiatan program dakwah yang wajib dilaksanakan seluruh peserta didik yang beragama islam. Kegiatan ini lebih fokus terhadap pembentukan akhlak dan pengamalan praktek ibadah siswa baik di sekolah maupun di luar sekolah.

\section{2) Program Kegiatan dakwah sebagai Sarana Penanaman PAI}

Program kegiatan dakwah yang di adakan di sekolah sebagai sarana penanaman PAI dilakukan setiap hari di SMP 11 Maret Kec. Ambarawa Kab. Pringsewu. Siswa diwajibkan untuk mengikuti kegiatan tersebut adalah siswa yang beragama islam. Siswa yang tidak mengikuti kegiatan tersebut akan diberikan sangsi atau hukuman tegas dari sekolah. Siswa yang non muslim diperintahkan untuk belajar di dalam kelas sampai kegiatan selesai dilaksanakan.

Program kegiatan dakwah ini bermula dari sikap dan perilaku siswa yang dinilai kurang baik dan kurang sopan terutama pada guru atau orang yang lebih tua. Guru dan kepala sekolah pada saat itu merasa kesusahan dalam memperbaiki sikap dan perilaku siswa di sekolah. Hal ini disebabkan dukungan orang tua, lingkungan masyarakat dan lingkungan sekolah yang kurang mendukung.

Dengan adanya program kajian dakwah yang dilakukan setiap hari bertujuan untuk merubah sikap dan perilaku siswa yang kurang baik menjadi lebih baik. Program kegiatan dakwah ini terus berlangsung dan dengan proses yang terjadi secara kontinu ternyata sudah menunjukkan hasil yang berbeda dari sikap dan perilaku yang sebelumnya tidak ada program kajian dakwah di sekolah. Penanaman PAI mulai menunjukkann hasil yang lebih baik dari sebelumnya, dalam hal ini dapat dikatakan bahwa program kajian dakwah keagamaan di sekolah sebagai sarana penanaman PAI memberikan dampak dan hasil yang positif.

Pengembangan kepribadian, karakter serta pengamalan praktek ibadah siswa merupakan inti dari pengembangan kegiatan dakwah yang dilakukan di SMP 11 Maret Kec. Ambarawa Kabupaten Pringsewu. Pengembangan dan penanaman nilai-nilai pendidikan islam dalam konteks program wajib sekolah diberikan kepada peserta didik dalam rangka membangun semangat siswa dalam menjalankan syariat agama islam pada umumnya, dan praktek ibadah siswa pada khususnya. Siswa dididik untuk memiliki kesadaran dalam menjalankan ibadah, menghargai orang lain, bersikap kritis serta peduli terhadap lingkungan sekolah. Kegiatan keagamaan tersebut dilakukan secara bersama-sama (learning to be live) di lingkungan sekolah. Siswa dan guru diwajibkan untuk ikut serta dalam setiap kegiatan keagamaan yang ada.

\section{3) Bentuk-bentuk Program Dakwah Keagamaan}

Program dakwah yang telah diterapkan di SMP 11 Maret Kec. Ambarawa menjadi salah satu program unggulan dalam membina dan membimbing siswa untuk selalu tekun beribadah dan beramal sholeh. Program ini juga berperan dalam peningkatan kesadaran moral beragama dan akhlak peserta didik. Mengingat sebelum ada program dakwah, peserta didik sudah mulai luntur sikap unggah-ungguh (sikap menghormati) terhadap guru atau orang yang lebih tua, sikap tidak disiplin dan cenderung dengan prilaku yang tidak baik (tercela). Kesadaran belajar sebagai tugas wajib bagi seorang siswa atau pelajar juga terlihat kurang maksimal.

Dalam konteks Pendidikan Nasional hal itu dapat dikembangkan sesuai dengan jenis kegiatan yang terdapat pada lampiran Kepmen Diknas No. 125 /U/2002 antara lain: 1) pesantren kilat, 2) tadarus, 3) shalat berjamaah, 4) shalat tharawih, 4) latihan dakwah, 5) baca tulis Al Qur'an, 6) pengumpulan zakat, 7) menghadirkan penceramah dari luar sekolah.

\section{a) Ceramah Agama}

Kegiatan ceramah agama dilaksanakan pada setiap 2 minggu sekali, jadwal pelaksanaanya adalah hari jum'at pagi setelah bel berbunyi. Kegiatan ini dilaksanakan di halaman sekolah. Sebelum kegiatan dakwah dalam hal ini adalah siraman rohani (ceramah agama) dilakukan terlebih dahulu siswa beserta guru melakukan sholat dhuha berjama'ah. Pelaksanaan sholat dhuha berjamaah ini diharapkan mampu menumbuhkan rasa cinta dan senang beribadah.

Ceramah agama dilakukan oleh penceramah agama dari luar yang dihadirkan oleh pihak sekolah. Kegiatan tersebut diikuti seluruh peserta didik dan guru. Isi dari ceramah agama bertujuan untuk meningkatkan pengetahuan keagamaan, kesadaran melaksanakan ibadah, dan meningkatkan akhlak siswa.

\section{b) Shalat Dhuha}

Sholat dhuha dilaksanakan oleh siswa setiap hari. Shalat dhuha yang terjadwal setiap hari ini menjadi salah satu program wajib kegiatan peribadahan siswa. Teknis pelaksanaan shalat dhuha yang dilakukan peserta didik dengan cara di gilir (terjadwal) perkelas setiap harinya. Pelaksanaan shalat dhuha yang terjadwal perkelas karena lokasi mushala sekolah yang hanya bisa menampung jumlah peserta didik satu kelas. Kegiatan sholat dhuha ini diharapkan siswa 
mengenal dan mempraktekan amalan ibadah sholat sunah. Harapan yang lebih dari sekolah adalah siswa mampu melaksanakan ibadah sholat sunah selain sholat sunah dhuha, seperti sholat sunah tahajud, dan lain sebagainya.

\section{c) Shalat Dhuhur}

Berbeda dengan sholat dhuha, pihak sekolah juga berkeinginan untuk mempunyai siswa yang kuat dalam hal ibadah wajibnya yaitu sholat wajib 5 waktu. Untuk itu, maka kemudian sekolah menempatkan sholat dhuhur sebagai sarana untuk menumbuhkan siswa akan kewajiban sholat fardu (wajib) 5 waktu. Shalat dzuhur dilakukan secara berjamaah. Teknis pelaksanaan shalat dhuhur yang dilakukan peserta didik dengan cara di gilir (terjadwal) perkelas sebagaimana praktek ibadah sholat dhuha.

\section{d) Kegiatan Pesantren Kilat}

Pesantren kilat merupakan kegiatan pesantren yang dilaksanakan pada saat liburan sekolah di bulan Ramadhan atau di luar Ramadhan. Pesantren Kilat disebut juga Pesantren Ramadhan apabila dilaksanakan pada bulan Ramadhan. Rentang waktu pelaksanaan pesantren kilat dilakukan 7 hari.

Tujuan pelaksanaan pesantren kilat lebih diarahkan kepada aspek pengamalan. Maka proses pembelajarannya lebih difokuskan kepada aspek afektif dan psikomotorik, dalam bentuk praktek dan latihan-latihan. Kegiatan pesantren kilat dilakukan dengan menyesuaikan situasi, kondisi dan potensi yang ada di sekolah. Pesantren kilat dilaksanakan oleh seluruh siswa di lingkungan SMP 11 Maret Kec. Ambarawa, sedangkan bapak dan ibu guru, staf sekolah menjadi panitia pelaksana dengan dibantu oleh ustadz-ustadz yang mengisi kegiatan ceramah agama.

\section{e) Ibadah Ramadhan}

Kegiatan ini merupakan salah satu kegiatan SMP 11 Maret Kec. Ambarawa yang dilakukan selama bulan suci Ramadhan. Dengan rentang waktu mulai malam pertama shalat tarawih sampai dengan kegiatan halal bil halal (saling maafmemaafkan) yang dilaksanakan dalam nuansa perayaan hari raya Idul Fitri. Kegiatan ibadah bulan suci Ramadhan antara lain meliputi: salat wajib, salat tarawih, salat sunat lainnya, tadarrus, buka bersama, pesantren kilat, zakat fitrah, santunan anak yatim, mendengarkan ceramah di masjid, mushola di televisi dan lain sebagainya sampai dengan kegiatan halal bi halal.

Melalui kegiatan Ibadah Ramadhan bagi peserta didik tingkat SMP 11 Maret Kec. Ambarawa, diharapkan para peserta didik lebih memahami, menghayati dan makin banyak mengamalkan nilainilai ajaran Islam. Kegiatan ibadah Ramadhan juga menjadi wahana bagi pembinaan watak, moral dan mental spiritual siswa sekolah, yang dapat membantu mewujudkan tercapainya tujuan penyelenggaraan PAI.

\section{f) Wajib Belajar Membaca dan Menulis Al Qur'an}

Belajar membaca menulis Al qur'an merupakan kegiatan yang wajib diselenggarakan dalam rangka memberikan kemampuan dan pengetahuan siswa dalam membaca dan menulis Al qur'an dengan baik dan benar. Kemampuan membaca dan menulis Al qur'an merupakan keterampilan dasar yang harus dimiliki oleh setiap orang yang beragama islam. Fungsi dari membaca dan menulis Al qur'an dengan baik adalah sebagai alat untuk mengetahui, memahami, menghafal dan mempelajari agama islam. Karena itu, belajar membaca dan menulis Al Qur'an perlu diselenggarakan secara khusus, sehingga diharapkan peserta didik yang lulus dari sekolah tidak buta membaca dan menulis $\mathrm{Al}$ qur'an.

Pelaksanaan membaca dan menulis Al qur'an antara lain dapat ditempuh dengan cara guru mewajibkan peserta didik mengaji dirumah atau mengadi di Madrasah Diniyah. Guru Mata pelajaran PAI mengadakan program khusus belajar membaca dan menulis Al qur'an di sekolah, di luar jam mata pelajaran yaitu pada saat pesantren kilat.

\section{g) Peringatan Hari Besar Islam}

Kegiatan memperingati hari besar islam dengan maksud syiar islam sekaligus menggali arti dan makna dari suatu hari besar islam. Hari besar islam yang dimaksud antara lain; Bulan Maulid, Isra Mi'raj, Nuzulul Qur'an, dan Tahun Baru Islam atau bulan Muharram, Iedul Fitri dan Idul Adha. Kegiatan tersebut memiliki makna pembelajaran bagi siswa. Pelaksanaannya adalah pihak sekolah menghadirkan nara sumber yang berkompeten dari luar menerangkan makna dan sejarah hari besar yang diselenggarakan. Dalam kegiatan tersebut, siswa juga dilibatkan seperti menampilkan kesenian islam (Kepala sekolah:2016).

\section{4) Implikasi Program Dakwah terhadap Sikap dan Akhlak siswa}

Peningkatan sikap dan akhlak siswa berdasarkan pengamatan sudah mengalami perubahan dari pada sikap dan akhlak yang sebelumnya, perubahan itu belum secara keseluruhan baru beberapa dimensi pemahaman agama dan peribadahan agama yang mengalami perubahan.

Dalam pengamatan yang dilakukan oleh peneliti siswa masih kurang mencapai target perubahan yang signifikan pada dimensi pelaksanaan ibadah sholat sunah. Siswa masih melakukan dengan rentang kadang-kadang, namun hal tersebut telah menunjukkan perubahan yang membaik dari yang sebelumnya tidak pernah dilaksanakan.

Peningkatan sikap dan akhlak siswa dapat dilihat dari hasil kuisioner yang telah dibagikan dan dari hasil observasi, selain itu data penelitian lebih diperkuat dengan hasil wawancara kepada kepala 
sekolah sebagai kordinator dari program kajian dakwah tersebut dan dengan guru di sekolah sebagai pengawas dari pelaksanaan program kajian dakwah tersebut.

Berdasarkan hasil analisis data ditemukan bahwa tingkat sikap dan akhlak siswa mengalami perubahan ke arah yang lebih baik. Hal ini bisa dilihat dari prosentase dari item kuisioner yang berkaitan dengan sikap dan akhlak siswa. Beberapa item yang berkaitan dengan akhlak siswa yaitu:

a) Bersalaman atau berpamitan dengan orang tua

ketika akan berangkat sekolah

Bersalaman atau berpamitan dengan orang tua merupakan salah satu dari akhlak yang harus ada dalam diri seorang siswa. Berdasarkan hasil penelitian sikap atau akhlak yang tersebut mengalami peningkatan yaitu dari yang sebelumnya $5 \%$ menjadi $40 \%$ (selalu), sedangkan untuk kategori sering dan kadangkadang mengalami penurunan, dari $55 \%$ menjadi $27,5 \%$ (sering) dan 37,5 menjadi $30 \%$ (kadang-kadang). Untuk kategori tidak pernah masih berada pada angka yang sama yaitu 2,5 $\%$ atau 1 responden.

b) Bersalaman dengan bapak ibu guru

Tidak berbeda jauh dengan item sikap no 1 . Sikap atau akhlak siswa ini juga mengalami peningkatan yaitu $20 \%$ menjadi $55 \%$ (selalu), $55 \%$ menjadi $27,5 \%$ (sering) dan $25 \%$ menjadi $17,5 \%$ (kadang-kadang). Ini menunjukkan adanya perubahan dari kategori sering dan kadang-kadang menjadi kategori selalu yaitu sebesar $35 \%$.

c) Menyapa bapak ibu guru terlebih dahulu ketika berpapasan

Sikap dan prilaku siswa berkaitan dengan praktek bersalaman dengan bapak ibu guru sebesar $55 \%$ (selalu), $27.5 \%$ (sering) dan $17,5 \%$ (kadang-kadang). praktek ibadah ini mengalami peningkatan jika dibandingkan dengan sebelum adanya program dakwah keagamaan, yakni $20 \%$ (selalu), $55 \%$ (sering), 25 (kadang-kadang). Berdasarkan data tersebut menggambarkan adanya peningkatan sebesar $35 \%$ siswa selalu melakukan praktek ibadah tersebut.

d) Ketika melakukan kesalahan segera menyadari dan meminta maaf

Prilaku sadar terhadap kesalahan tang telah dilakukan dan meminta maaf ketika berbuat salah kepada orang lain merupakan hal yang tidak mudah untuk dilakukan. Inilah yang kemudian menjadi penting untuk menanamkan rasa sadar akan kesalahan yang telah diperbuat dan meminta maaf kepada para siswa disekolah. Berkaitan dengan hal tersebut, hasil penelitian yang telah dilakukan menunjukkan bahwa terdapat $47,5 \%$ siswa berada pada kategori selalu, 27,5\% (sering), dan $25 \%$ (kadang-kadang). Hal ini menunjukkan adanya peran program dakwah yang ditanamkan di sekolah SMP 11 Maret Sumberagung.

e) Membantu teman ketika mengalami kesusahan Salah satu akhlak yang ditekankan dalam islam dalam hal persaudaraan adalah membantu teman ketika masih mengalami kesusuhan. Akan tetapi prilaku tersebut ternyata masih belum tertanam dengan baik di sekolah SMP 11 Maret, walaupun ada peningkatan dari sebelum adanya program dakwah ini. Berdasarkan data menunjukkan hanya 22,5\% siswa (selalu), 32,5 \% (sering), 42,5 \% (kadang-kadang) dan $2.5 \%$ (tidak pernah).

\section{5) Implikasi Program Dakwah terhadap Praktek Ibadah Siswa di Sekolah}

Implikasi program kegiatan dakwah terhadap praktek ibadah siswa di sekolah mengalami perubahan yang signifikan dan membaik, hal ini terlihat dari kegiatan ibadah siswa yang tidak pernah dilakukan sekarang terlihat sering dilakukan di sekolah. Dalam hal ini kegiatan dakwah sangat dianjurkan untuk dilakukan di sekolah-sekolah umum yang tidak berbasis keagamaan.

SMP 11 maret ini tidak hanya menerima siswa yang beragama islam namun semua dapat diterima, hal tersebut tidak mengurangi sedikitpun niat untuk diadakanya program kajian dakwah ini dalam waktu seminggu sekali yang bertepatan dengan hari jum'at. Menurut kepala sekolah SMP 11 maret hari jum'at dipilih karena sebelumnya kegiatan hari jum'at siswa melakukan senam pagi, namun dengan senam pagi setiap jum'at tidak merubah sikap dan perilaku siswa yang kurang baik. Dengan adanya program kajian dakwah di sekolah diharapkan sikap dan perilaku siswa yang kurang berkenan ata kurang baik dapat berubah dengan pesat. ${ }^{1}$

Berdasarkan hasil penelitian menyatakan bahwa adanya peningkatan persentase dari sebelum adanya program dan setelah adanya program kajian dakwah di sekolah yaitu sebesar 24,1\%. Di sisi lain praktek ibadah siswa secara umum mengalami peningkatan dengan tingkat yang berbeda-beda. Untuk lebih jelasnya akan diuraikan berdasarkan item masing-masing praktek ibadah yang dilaksanakan oleh siswa SMP 11 Maret kec. Ambarawa Kab. Pringsewu.

a) Berdoa sebelum memulai kegiatan belajar.

Berdoa sebelum memulai kegiatan belajar merupakan praktek ibadah yang wajib dilakukan. Hal ini sudah sangat jelas dan dapat dilihat dari kurikulum maupun dari perangkat pembelajaran di sekolah, praktek ibadah berdoa sebelum memulai kegiatan belajar merupakan bagian kegiatan apersepsi di rencana pelaksanaan pembelajaran. Berdoa sebelum 
memulai kegiatan belajar ini merupakan kegiatan yang biasa dilakukan dan terkesan sangat mudah, namun hal ini terkadang masih sering terlewatkan untuk dilakukan, sehingga hal tersebut merupakan salah satu alasan untuk diukur dalam penelitian ini.Pernyataan ini mengalami peningkatan $43 \%$ dari sebelumnya adanya penerapan program sebesar $32,5 \%$ menjadi $75,0 \%$. Secara rinci dijelaskan bahwa yang menjawab selalu $(75,0 \%)$, sering $(15,0 \%)$, dan kadang-kadang (10,0\%). Peningkatan $43 \%$ dilihat dari jawaban siswa selalu melakukan pernyataan tersebut.

b) Berdo'a setelah kegiatan belajar di kelas selesai

Pernyataan praktek ibadah no dua ini tidak berbeda jauh dengan Pernyataan praktek ibadah no satu. Berdoa setelah kegiatan belajar dikelas selesai merupakan praktek ibadah yang wajib dilakukan. Hal ini sudah sangat jelas dan dapat dilihat dari kurikulum maupun dari perangkat pembelajaran di sekolah, praktek ibadah berdoa setelah kegiatan belajar merupakan bagian kegiatan penutup di rencana pelaksanaan pembelajaran. Berdoa setelah kegiatan belajar ini merupakan kegiatan yang biasal dilakukan dan terkesan sangat mudah, namun hal ini terkadang masih sering terlewatkan untuk dilakukan, sehingga hal tersebut merupakan salah satu alasan untuk diukur dalam penelitian ini. Pernyataan ini mengalami peningkatan. Dan dalam pernyataan ini ada peningkatan $32 \%$ dari yang sebelumnya adanya penerapan program sebesar $30,0 \%$ menjadi $62,5 \%$.Secara rinci dijelaskan bahwa yang menjawab selalu $(62,5 \%)$, sering $(30,0 \%)$, dan kadang-kadang (7,5\%). Peningkatan $32 \%$ dilihat dari jawaban siswa selalu melakukan pernyataan tersebut.

c) Menjalankan sholat wajib 5 waktu

Menjalankan sholat wajib 5 waktu merupakan praktek ibadah yang wajib dilakukan oleh semua umat yang beragama muslim atau islam. Praktek ibadah ini sifatnya wajib namun sebagian siswa ada yang belum menyadari kewajiban tersebut untuk dilaksanakan. Dengan alasan tersebut peneliti menjadikan hal tersebut sebuah indikator yang harus diukur ketercapaiannya. Selain itu praktek ibadah ini berkaitan dengan program yang dilaksanakan di sekolah. Berdasarkan data menunjukkan bahwa adanya peningkatan $25 \%$ dari yang sebelum penerapan program sebesar 2,5\% menjadi $27,5 \%$. Secara rinci dijelaskan bahwa yang menjawab selalu $(27,5 \%)$, sering $(45,0 \%)$, dan kadang-kadang $(27,5 \%)$. Peningkatan $25 \%$ dilihat dari jawaban siswa selalu melakukan pernyataan tersebut. d) Menjalankan sholat dhuha di sekolah

Menjalankan sholat dhuha di sekolah merupakan bagian dari program yang dilaksanakan di sekolah dan pernyataan ini merupakan praktek ibadah yang sedang dijadikan sebuah kebiasaan untuk dilakukan siswa setiap hari jum'at khususnya sebelum mendapatkan tausiyah dan akan dijadikan kebiasaan di hari-hari yang lain. Praktek ibadah ini mengalami peningkatan yang signifikan yaitu $30 \%$ dari yang sebelum penerapan program sebesar $0 \%$ menjadi $30 \%$. Secara rinci dijelaskan bahwa yang menjawab selalu (30\%), sering (45\%) dan kadang-kadang (25,0\%). Peningkatan $30 \%$ dilihat dari jawaban siswa selalu melakukan pernyataan tersebut.

e) Menjalankan sholat tahajud

Praktek ibadah menjalankan sholat tahajud merupakan ibadah yang sunah dilakukan namun hal ini perlu dilakukan agar praktek ibadah seorang muslim lebih baik lagi. Selain itu pernyataan ini perlu diukur karena ingin mengetahui seberapa besar praktek ibadah ini dilaksanakan dan dijalankan oleh siswa. Berdasarkan hasil data penelitian menunjukkan bahwa adanya peningkatan sebesar $42,5 \%$ dari yang sebelum penerapan program $25,0 \%$ menjadi $67,5 \%$. Secara rinci dijelaskan bahwa yang menjawab sering $(10,0 \%)$, kadang-kadang $(67,5 \%)$ dan tidak pernah $(22,5 \%)$. Peningkatan dilihat dari jawaban siswa yang menjawab kadang-kadang.

f) Membantu kedua orang tua ketika pulang sekolah

Membantu kedua orang tua ketika pulang sekolah merupakan bagian dari praktek ibadah dan merupakan bagian dari implikasi program yang dilaksanakan di sekolah setiap hari jum'at. Pernyataan ini perlu diukur dan diketahui untuk mengetahui ada perubahan yang signifikan pada diri siswa setelah penerapan program dakwah setiap hari jum'at. Berdasarkan hasil data penelitian menunjukkan bahwa adanya peningkatan sebesar $40 \%$ dari yang sebelum adanya penerapan program $12,5 \%$ menjadi 52,5\%. Secara rinci dijelaskan bahwa yang menjawab selalu $(52,5 \%)$ dan sering (47,5\%). Peningkatan dilihat dari jawaban siswa yang menjawab selalu.

g) Mengerjakan sholat saya diperintah orang tua Pernyataan ketujuh ini tidak berbeda jauh dengan pernyataan yang lain, bahwa mengerjakan sholat merupakan praktek ibadah. Namun, sedikit berbeda dengan pernyataan yang mengerjakan sholat 5 waktu, karena dalam pernyataan ini siswa akan diukur dan perlu diketahui bahwa sholat merupakan kewajiban dan kesadaran diri atau hanya karena diperintah orang tua. Pernyataan ini 
merupakan bagian dari pernyataan yang mendukung program dan harus diukur dari ketercapaian penerapan program tersebut di sekolah. Indikator mengerjakan sholat saya diperintah orang tua mengalami penurunan $40,0 \%$ dari yang sebelumnya mencapai $45,0 \%$ menjadi $5,0 \%$. Secara rinci dijelaskan bahwa yang menjawab sering $(5,0 \%)$, kadang-kadang $(42,5 \%)$, dan tidak pernah $(52,5 \%)$. Penurunan dilihat dari jawaban siswa yang menjawab sering. Data tersebut menunjukkan bahwa program yang dilaksanakan di sekolah mencapai tahap keberhasilan.

h) Membiasakan berinfaq di masjid

Membiasakan berinfaq di masjid merupakan praktek ibadah yang lebih sering disebut beramal. Pernyataan ini merupakan bagian dari implikasi program yang dilaksanakan di sekolah, sehingga pernyataan ini perlu untuk diukur dan diketahui. Data penelitian menunjukkan bahwa ada peningkatan sebesar $25 \%$ dari yang sebelum adanya penerapan program $10,0 \%$ menjadi $35,0 \%$. Secara rinci dijelaskan bahwa yang menjawab sering $(35,0 \%)$, kadang-kadang $(55,0 \%)$ dan tidak pernah $(5,0 \%)$. Peningkatan dilihat dari jawaban siswa yang menjawab sering.

i) Segera melakukan sholat setelah mendengar adzan.

Praktek ibadah segera melakukan sholat setelah mendengar adzan merupakan praktek ibadah yang dinilai cukup sulit untuk dilaksanakan, mengingat siswa masih banyak yang belum memiliki kesadaran akan kewajiban untuk beribadah. Hal tersebut membuat peneliti ingin mengetahui peningkatan yang signifikan dari implikasi program yang diterapkan disekolah. Pernyataan ini mengalami peningkatan $12,5 \%$ dari yang sebelum adanya penerapan program $2,5 \%$ menjadi $15,0 \%$. Secara rinci dijelaskan bahwa yang menjawab selalu $(15,0 \%)$, sering $(37,5 \%)$ dan kadang-kadang (47,5\%). Peningkatan dilihat dari jawaban siswa yang menjawab selalu.

j) Menjalankan sholat ketika sedang sakit

Menjalankan sholat ketika sedang sakit merupakan praktek ibadah yang dinilai sedikit sulit untuk diterapkan, pernyataan ini sangat penting untuk diketahui dan diukur karena mengingat pernyataan ini merupakan bagian dari implikasi penerapan program di sekolah. Data menunjukkan bahwa adanya peningkatan $7,5 \%$ dari yang sebelum adanya penerapan program $7,5 \%$ menjadi $15,0 \%$. Secara rinci dijelaskan bahwa yang menjawab selalu $(15,0 \%)$, sering $(15,0 \%)$, kadang-kadang $(32,5 \%)$ dan tidak pernah $(37,5 \%)$. Peningkatan dilihat dari jawaban siswa yang menjawab selalu. Hasil data tersebut menunjukkan bahwa implikasi dari penerapan program mengalami peningkatan yang baik.

\section{Faktor Pendukung dan Penghambat}

Adapun hal-hal yang menjadi faktor pendukung dalam program dakwah yang di selenggarakan SMP 11 Maret Kec. Ambarawa Kab. Pringsewu adalah: Pertama, Program tersebut adalah program yang diwajibkan, yang harus diterapkan oleh sekolah atas intruksi dan dukungan penuh dari pihak yayasan. Pihak yayasan memberikan support (dukungan) penuh baik bersifat materiil maupun non materiil. Sumber pendanaan program dakwah tersebut langsung dari pihak yayasan. Kedua, Kepala sekolah, Wakasek, bidang kurikulum, Tenaga Pembina dan Warga Sekolah dan seluruh peserta didik telah berpartisipasi dan terlibat langsung dalam setiap program kegiatan keagamaan yang diselenggarakan di sekolah dengan sangat baik. Terbukti dengan kehadiran peserta didik yang antusias dalam mengikuti program tersebut. Ketiga, adanya sanksi yang mendidik terhadap peserta didik yang tidak mengikuti salah satu program dakwah. Hal ini dimaksudkan untuk menanamkan disiplin peserta didik.

Faktor penghambat dalam pelaksanaan program dakwah SMP 11 Maret Kec. Ambarawa Kab. Pringsewu adalah: Faktor sarana dan prasarana. Mushala yang kecil yang hanya cukup menampung peserta didik satu kelas, air yang terbatas, serta jumlah buku-buku keagamaan yang masih perlu ditingkatkan kuantitasnya.

\section{E. PENUTUP}

\section{1) Kesimpulan}

Dari hasil penelitian ini dapat diambil kesimpulan bahwa program dakwah yang dikembangkan di SMP 11 Maret Kec. Ambarawa Kab. Pringsewu adalah ceramah agama, Shalat Dhuha, Shalat Dhuhur berjamaah, kegiatan Pesantren Kilat, ibadah Ramadhan, Wajib Belajar Membaca dan Menulis Al Qur'an, memperingati hari besar Islam. Melalui program dakwah yang bersifat harian, mingguan maupun tahunan mulai menunjukkan proses perubahan ke arah yang lebih baik.

Inti dari pengembangan program dakwah yang dilakukan di SMP 11 Maret Kec. Ambarawa Kabupaten Pringsewu adalah menanamkan nilainilai pendidikan Islam, membangun karakter mulia dan praktek ibadah siswa. Siswa di didik untuk memiliki kesadaran dalam menjalankan ibadah, menghargai orang lain, bersikap kritis serta peduli terhadap lingkungan sekolah. Hal ini ditunjukkan dengan hasil penelitian yang menggambarkan adanya peningkatan yang lebih baik dari segi akhlak maupun ibadah siswa. Ketercapaian tersebut tidak lepas dari dukungan pihak sekolah dan orang tua. 


\section{2) Saran}

Program dakwah sebagai upaya membangun akhlak dan ibadah siswa hendaknya dikelola secara baik dan profesional. Dalam pelaksanaan program tersebut, siswa diharapkan untuk selalu mendukung semua kegiatan yang ada dan dapat bekerja sama, sehingga program dakwah sebagai program ekstra kurikuler keagamaan dapat terus berkembang serta dapat lebih meningkatkan penanaman nilai-nilai pendidikan Islam.

Dalam rangka meningkatkan program dakwah yang telah berjalan dengan baik, maka perlu ditingkatkan lagi sarana dan pra sarana seperti perluasan mushala, tempat wudhu yang lebih baik, laboratorium PAI, media Audio Visual. Inovasi kegiatan dari segi format pembelajaran, materi yang diajarkan, pemusatan tempat pelaksanaan dan hubungan masyarakat perlu ditingkatkan lagi.

\section{DAFTAR PUSTAKA}

Amin, Masyhur. 1997. Dakwah Islam dan Pesan Moral. Yogyakarta: Al Amin Press.

As-Sahlani, Muhammad, At-Tarbiyah wa at-Ta'lim fi al-Qur'an al-Karim. Majalah At-Tauhid, No 8, Tahun II, Sya'ban, 1404 H, h. 288.

Ash-Shiddiqy, Hasby. 2000. Kuliah Ibadah. Semarang: PT Pustaka Rizki Putra.
Hidayat, Helmi. 1994. Menuju Kesempurnaan Akhlak. Bandung: Mizan.

Ibn Miskawaih. 1405H/1985M. Tahzib Al-Akhlaq. Beirut: Daar Al- Kutub Al-Ilmiyyah.

Ilyas, Yunahar. 2009. Kuliah Akhlak. Yogyakarta:Pustaka Pelajar.

Nasr, Seyyed Hossein. 2002. Ensiklopedi Tematis Spiritualitas Islam. Bandung: Mizan Media Utama.

Soejoeti, Zarkawi. 2002. Konstektualisasi Ajaran Islam. Semarang: Walisongo Press.

Syukir, Asmuni. 1983. Dasar-dasar Strategi Dakwah Islam. Surabaya: Al-Ikhlas.

Undang-undang Nomor 20 Tahun 2003 tentang Sistem Pendidikan Nasional.

Wahyudi. 2009. Pengembangan Materi Seni Budaya Lelagon Dolanan Anak Laras Slendro Pelog Sebagai Upaya Pengenalan, Pelestarian, dan Penanaman Nillai Nilai Budaya Jawa Bagi Siswa SD/MI di Jawa Tengah, Skripsi. Surakarta: Universitas Sebelas Maret Surakarta.

http://beritalampung.blogspot.co.id/2010/06/beritalampung-komisi-nasional.html.di-akses, 2 Juni 2016. 